\title{
Understanding the Southern Italian commons: polycentric governance on the mountains of Sila
}

\author{
Claudio de Majo* \\ Rachel Carson Center for Environment and Society, Ludwig Maximilian University, Munich
}

(Received 23 May 2018; final version accepted 12 March 2019)

\begin{abstract}
In this article, I examine patterns of collective action in the South of Italy, a region where commons scholarship presents several challenges, mainly due to its feudal heritage. In analysing the history of Southern Italian commons, Elinor Ostrom's theories on polycentric governance are adopted. I propose a case study on the mountains of Sila, where collective action was institutionalised through a municipal organisation known as universitas casalium, consisting of the city of Cosenza and its hamlets. This institution collaborated with the royal government, creating a polycentric governance system where institutional functions contentiously intermingled, generating conflicting relations, but also unique governmental arrangements. Yet how did previous historical interpretations miss this point? Documentary evidence provides a clear answer: while the institutional recognition of the universitas casalium can be traced back as far as the twelfth century, a series of institutional reforms initiated in the mid-fifteenth century led to the progressive decline of the local institution and accordingly of the commons economy related to it. This loss of legitimacy derived from the emergence of feudal barons and later of landowners from the middle class, leading to the progressive dissolution of collective action in Sila as Italy moved towards Italian unification in 1861.
\end{abstract}

Keywords: commons; Southern Italy; Elinor Ostrom; polycentric governance; Sila.

\section{Introduction}

For centuries the history of Italy has been characterised by collective action, especially in rural areas. In several territories, local socioeconomic structures rested on collective forms of ownership organised on common lands and defined by customary norms (Corona 2009). Although today one could easily consider similar governance arrangements in rural area to be commons, Italian academic scholarship has only recently begun to rediscover this topic, mainly thanks to Elinor Ostrom's inspiring work (1990). While political and economic studies have attempted to frame the commons in the modern Italian context (Ricoveri 2010; Cacciari 2010; Pennacchi 2012), historians are confronted with the task of analysing different patterns of collective action in rural areas, drawing comparisons and detecting institutional and geographical specificities (Massullo 2015, 13). The task is anything but easy, considering the fragmented history of the country during almost thirteen centuries, a 'hurly-burly of peoples, states and institutions' (Duggan 2014, 2), with a timespan starting from the fall of the western Roman Empire in 476 and ending with the national unification of the peninsula in 1861. In particular, the so-called Italian Mezzogiorno has benefited from little attention, due to its feudal heritage, in sharp contrast to the city-state tradition of Northern and Central Italy.

\footnotetext{
*Email: Claudio.DeMajo@rcc.lmu.de
} 
This has generated an interpretive divide: while in Northern and Central Italy patterns of collective action have been acknowledged, the feudal tradition of Southern Italy has favoured a historical interpretation that sees the commons as a marginal actor in a universe dominated by a centralising monarchy, feudal lords and ecclesiastical powers. Perhaps the most striking example comes from Paolo Grossi's masterpiece on the legal history of Italian collective ownership, Un altro modo di possedere (1977). Although the book manages to trace a comprehensive picture of the commons in Italy, emphasising their shared underlying ideals and their resilience against agrarian individualism, it also insists on the different historical trajectories of collective action in Southern Italy, implicitly perpetuating the idea of a centralised organisation of the commons (Corona 2004).

The aim of this article is to produce a divergent historical interpretation of the commons in Southern Italy, one that stems from the interpretations cited above. First, using the vast corpus of legal studies on collective ownership, this research demonstrates the normative origin of Southern Italian commons by reconstructing the notion of customary rights, the first legal regulation of collective action produced during the Roman Age. Second, I analyse the peculiarity of Southern Italian commons more in detail, undertaking a case study on the uplands of Sila, a naturally rich territory located in central Calabria, where collective action functioned through a complex intermingling of institutional arrangements and local regulations. This allowed the second most densely populated municipal institution of the Italian Mezzogiorno - the so-called universitas casalium - to create a thriving commons economy. The example of Sila reinforces the article's underlying argument about the effectiveness of governance patterns based on collective action in the feudal context of Southern Italy. It also demonstrates the region's peculiar administrative structures, where multiple governance patterns and land regulations factiously overlapped, leading to outcomes both positive and negative.

While Southern Italian commons functioned effectively, they were progressively delegitimised by royal institutions as the result of a reformist campaign initiated during the first half of the fifteenth century. This caused a slow and inexorable decline of collective action, favouring the rise of agrarian individualism - what Gabriella Corona has defined as a long and non-linear historical process that led to the expansion of agricultural frontiers through the privatisation of common lands $(1995,34)$.

\section{Research context and methodology}

The current research considers the commons as a particular category of property rights based on collective action and collective patterns of ownership and management (Wall 2017, 6). Drawing from Elinor Ostrom's theories, it looks at the commons as a heterogeneous governance system, with eight main characteristics:

1. Clearly defined boundaries;

2. Congruence between appropriation and provision rules and local conditions;

3. Collective-choice arrangements;

4. Monitoring;

5. Graduated sanctions;

6. Conflict-resolution mechanisms;

7. Minimal recognition of rights to organise;

8. Nested enterprises (Ostrom 1990, 90). 
In this article, particular emphasis is given to polycentric governance systems, a research line that has not enjoyed enough attention despite its popularity. Following Ostrom's lead, one could consider polycentric systems as complex forms of governance with multiple decision-making centres where collective action is equally characterised by resilient socio-ecological features, but at the same time potentially hampered by conflicting interests and rules (Ostrom 1990, 133-136 and 2005, 283). Carlisle and Gruby further develop Ostrom's theory, identifying three different ideas that lie at the core of polycentric governance systems: a) better adaptation capacities in facing social and environmental change; b) good institutional fits for complex natural resource systems; c) mitigation of the risks of institutional failures and resource losses $(2017,3)$.

This study looks at the polycentric governance systems that characterised Southern Italian collective action, leading to legal controversies and adaptive problems. Naturally, researching governance patterns of collective action is not a new or unique activity, considering that over the last few decades several historical studies have described the so-called 'silent revolution' of the commoners (De Moor 2017, 18 and 84) - that is, the institutionalisation of collective action in several western European countries (see Thompson 1991; De Moor 2008 and 2010; De Moor et al. 2016), including Italy (e.g. Alfani and Rao 2011; Bonan 2016 and 2018). However, few researchers have illustrated the historical process that led to the institutionalisation of Southern Italian commons (Corona 2009; Bulgarelli Lukacs 2015). By analysing the history of Southern Italian commons from the perspective of polycentric governance, this study attempts to include the Italian Mezzogiorno in the conversation.

In the first part of the text analysing the normative origins of collective action in the Italian peninsula, several institutional structures that developed during the Middle Ages are compared, through a comprehensive look at the judicial literature produced so far. This consists of both early judicial studies on customary rights (such as Cencelli 1920; Cassandro 1943; Zaccagnini and Palatiello 1984), as well as more recent studies that have successfully analysed the complex interplay between collective action and state regulations in Italy (such as Grossi 1977; Stagno \& Tigrino 2013; Marinelli 2013; Alfani and Rao 2011; Ciuffetti 2015; Mocarelli 2015). Moreover, in analysing the shared normative root of commons in Italy and the functionality of Southern Italian commons in the feudal context of Sila, the text implicitly addresses a historical debate on the relation between city-states and civic organisations on the Italian peninsula. In contrast to the theories formulated by political analysts, such as Banfield (1958) and Putnam (1993), this essay demonstrates the functionality of governance systems based on collective action in the Southern Italian feudal system.

While the first part of the article mainly relies on secondary sources, the case study of Sila makes reference to primary sources. Research on the commons can be a rather challenging task for historians, who normally need to look for traces of these traditional practices in the few legal documents available (De Moor 2017, 8). While in some Southern Italian territories institutional rules on collective action are the result of local community efforts (Bulgarelli 2015), in the case of Sila information on governance patterns is contained in royal decrees and deliberations. At the same time, several historical documents note the status of land distribution and provide valid information on customary rights, drawing a broad picture of collective action in Sila. This research is mainly grounded on this wide corpus of legal documents. First, an inquiry on the lands of Sila produced by Judge Giuseppe Zurlo in 1791, which combined a study of collective action and of land organisation; second, a collection of state laws collected by civil commissary Pasquale Barletta (1864); and third, most importantly, a collection of rules concerning the universitas casalium from 1333 to 1557 (Privilegii et capitoli della citta de Cosenza et soi casali 1557). These documents report internal regulation systems and demonstrate the serious royal attention paid to 
this institution. Further relevant data concerns information on the utilisation of common lands and legal proceedings against land grabbing and damaging local woods. These sources can be found in the collections of the State Archives of Naples (Regia Sila; Ministero delle finanze; Ministero di Polizia) and Cosenza (Demanio silano). In this sense, this case study connects with other recent research efforts that have emphasised the importance of legal documents in the study of the commons as evidence of management practices and power relations within local communities (De Moor et al. 2016, 534).

\section{Southern Italian exceptionalism: the coexistence of feudalism and customary rights}

\section{Customary rights in the Roman age: the 'invention' of usi civici}

Collective action in Italy was first institutionalised with the assimilation of customary laws by the Romans (Marinelli 2013, 407). These rules, in Italian known as usi civici, originated in the so-called ager publicus - the goods seized by the Roman Republic that were given in usufruct to its citizens ('usufruct' is a civil law term referring to the right of one individual to use the property of another, provided its substance is not impaired). The word 'use', in Latin usus, indicated a set of activities for the utilisation of a certain natural resource. During those times, usufruct was mostly conferred only to people who enjoyed citizenship status, the so-called cives (Zaccagnini and Palatiello 1984, 3-7). Although Roman 'civic uses' were legally restricted, in some cases they also assimilated ancient forms of customary rights - known as pre-Romanic or Italic - based on universal collectivism and unrestricted access (Cassandro 1943,44.). These traditional activities were characteristic of municipal organisations known as universitas. While they gained their denomination during Roman times, universitas originated in ancient family structures that determined the collective management of natural resources, structures that were subsequently assimilated by municipal institutions, becoming part and parcel of the civic apparatus (Bulgarelli Lukacs 2015, 123). Given their administrative function and their collective structure, they can be considered as indissolubly related to customary rights - the guardians of centuries-old traditions - and a universal patrimony belonging to the totality of community members (Bulgarelli Lukacs 2015, 125). Altogether, universitas constituted the institutional recognition of collective action on Italian lands, where different traditions and uses converged, fostering the formulation of numerous judicial doctrines (Corona 2009). In this sense, up to a certain point the institutionalisation of collective action on the Italian peninsula followed a historical path of consolidation, assimilating customary laws into national institutions, and creating a fictive legal persona that represented the community (De Moor 2017, 56-57).

\section{The medieval fragmentation of customary rights}

After the invasion of the Germanic people during the Middle Ages, the status quo of territorial organisation in the Italian peninsula was altered, as lands were redistributed among public institutions, private actors and communities. The legal status of common lands was actually reinforced by the principles of Germanic jurisprudence, turning customary rights into universal forms of collective action (Marinelli 2000, 26-27). While this process favoured the institutional assimilation of collective action, the Germanic penetration in Italy also led to the political fragmentation of the peninsula, determining jurisdictional differentiations and separate destinies for Northern-Central and Southern Italy (Ciuffetti 2015, 90-91).

In Northern and in Central Italy, the new political organisation of city-states - known as 'communes' - favoured the progressive assimilation of collective action into a tradition of civic union. This process coincided with the emergence of a new class of bourgeois owners free from the rule of 
feudal landlords, whose wealth relied on the stability of local farming systems based on collectivism (Sereni 1997, 202-203). Thus, the mutual reliance of these two social classes favoured the survival of collective arrangements among the local peasantry. Their characteristics were influenced by specific political and geographical contexts: they were called vicinie in the east-central Alps, communaglie in Liguria, comunanze in the Appennines of Umbria and Marche, and regole in the Cadore region of alpine Veneto (Corona 2009, 91-93). Especially in mountainous areas, these arrangements were largely impervious to major transformative forces, and in some cases their resilience can still be observed today (Mocarelli 2015, 65).

On the other hand, collective action in the South of Italy was assimilated into an enduring feudalism, creating a two-headed governance system where state legal norms and customary rights intermingled (Corona 2009, 368). This meant the transformation of public lands dating back to the Roman era into 'domain lands', territories owned by the Crown, following the judicial principle of Omnia Rex imperio possidet; singuli dominio (the king has sovereignty over every domain land). Hence, domain lands included all those territories over which the monarchy's rule extended and which the king chose to distribute among his subjects (Lombardi 1885, 32-33). There were four classifications of domain lands - the main dualism consisted in the division between royal domain lands (demani regi) and universal domain lands (demani universali). The former were lands available for the exclusive use of the king, where customary rights could be recognised through the payment of a canon tax, or bagliva, while compliance with the rules was guaranteed by local controllers, known as baglivi (Cassandro 1943, 210). The latter were built upon the already-mentioned universitas, and granted complete usufruct to local communities, who could access the natural resources of these territories and directly govern themselves (Raffaglio 1939, 22-40). In Southern Italy universal domain lands flourished considerably between the thirteenth and eighteenth centuries, with particular success on the slopes of the Southern Italian Apennines, above 500 metres altitude (Corona 2017, 28). To these two patterns of land division, two more were added later: feudal and ecclesiastical domain lands (territories assigned to barons and members of the church respectively). Despite this formal land division, in most cases local communities could still exercise some of their customary rights that granted them access to local natural resources (Corona 2009, 96). In particular, pasture lands, plains, mountain woods, water flows and other natural resources were considered as common resources and were placed under the direct jurisdiction of the local univeristas (Bulgarelli Lukacs 2015, 122-126). In this light, one could conclude that the current gap in the interpretation of collective properties in Southern Italy has resulted more from the complexity of its normative structures, rather than from the lack of self-organised patterns of collective action.

As shown by the table below (see Table 1), the governance patterns regulating collective action in Southern Italy were characterised by the contentious intermingling of national and local institutions. Naturally, this complexity could influence the resilience of local communities' customary usufruct practices. While in Northern and Central Italy common lands were protected both by local inhabitants and in many cases by local institutions, in Southern Italy the overlapping of different governance systems and patterns of land ownership could hardly accommodate diverging interests. Thus, local communities had to face various exogenous pressures: in many cases feudal landlords deliberately bypassed legal dispositions, privatising common lands. Royal authorities were not always able to stop these processes and in some cases they deliberately chose to avert their eyes to preserve economic interests and political stability (Villani 1977, 221-222). As will be shown by the case study offered below, in the uplands of Sila Germanic laws combined with customary rights, creating a multilevel polycentric governance system whose characteristics correspond to Elinor Ostrom's conceptualisation: controversies and violence, but also flexible and resilient arrangements $(2005,286)$. 
Table 1. Different patterns of collective action in Northern-Central and Southern Italy: simplicity versus complexity

\begin{tabular}{|l|l|l|}
\hline \multicolumn{1}{|c|}{$\begin{array}{c}\text { City-states system } \\
\text { (Northern-Central Italy) }\end{array}$} & \multicolumn{1}{c|}{ Feudal system (Southern Italy) } \\
\hline $\begin{array}{c}\text { Governance } \\
\text { Actors involved }\end{array}$ & City-level organisations & $\begin{array}{c}\text { National organisations, feudal } \\
\text { administrations, municipal organs }\end{array}$ \\
\hline Legislation & Local laws, consuetudinary norms & $\begin{array}{c}\text { National laws, local laws, } \\
\text { consuetudinary norms } \\
\text { communitrators, communities }\end{array}$ \\
\hline $\begin{array}{c}\text { Resources } \\
\text { involved }\end{array}$ & $\begin{array}{c}\text { Territories neighbouring the city } \\
\text { belonging to the community }\end{array}$ & $\begin{array}{c}\text { Territories belonging to the kingdom, } \\
\text { territories belonging to the feudal } \\
\text { barons, territories belonging to the } \\
\text { community. }\end{array}$ \\
\hline
\end{tabular}

\section{Collective action in Sila: the universitas casalium between institutional recognition and political independence}

\section{The mountains of Sila}

The uplands of Sila constitute one of the most bio-diverse areas of the Mediterranean environment (Ciolli 1982, 155-167). Since ancient times, the rich ecosystem of Sila has provided abundant resources for the inhabitants of its peaks and rugged valleys. Numerous human settlements were created around these territories, which relied mostly on sylvo-pastoral activities (Tallarico 1950, 13). The first settlers were known as Bruzi, a Lucan tribe whose material life was shaped by the rich bio-diversity of the surrounding environment (Galli 1959, 14). The subsistence activities of these people mainly consisted in cattle farming in the great mountain valleys - the already mentioned practice of transhumance - as well as wood gathering, fishing and some minor agricultural activities such as growing rye (Intrieri 2010, 5-6). The first trustworthy information on the political and economic history of Sila appears in legal registers dating back to the first half of the tenth century AD. During this time the Kingdom of Naples had to regulate access to the rich local woodlands that provided an essential raw material for naval construction, transforming the uplands of Sila into a royal domain land or demanio regio (Barletta, 1864). Particularly relevant are the three concessions emitted by the Normans, dated 31 May 1099, 1 June 1115 and 18 October 1149 (Barletta, 1864 vol. I, 3-9). Yet the legal status of Sila as a royal domain land was only made official by a decree promulgated by the Angevin king Robert (1277-1343) on 24 December 1333, defining it as 'nostro demanio' - literally, 'our domain land' (Barletta 1864 vol. 1, 55).

On the other hand, since the reign of Norman king Roger II of Sicily (1130-1154), collective action in Sila had already been officially recognised by the Crown, with the institutionalisation of the already mentioned universitas casalium, a municipal organisation comprising the city of Cosenza and its hamlets, known as casali (Placanica 1999, 166). This institution constituted for several centuries the main organ for the management of judicial power and regulated access to the natural resources of the area (Cozzetto 2005, 266). The first tangible evidence of the governance arrangements characterising the universitas casalium emerges during the reign of Frederick II (1198-1212) with the creation of the bagliva tax, which collected usufruct taxes from its citizens. 
The institutional recognition of the universitas casalium was later officialised by a royal decree promulgated in 1330 by King Robert of Anjou, defining the inhabitants of Cosenza and its hamlets as 'universitas et homine'. The same king later acknowledged the independence of the territory so designated, in 1333, meticulously describing its borders (Privilegii 1557, 113). These legislative acts endorsed collective action in the settlements around Sila, allowing its inhabitants to exercise their traditional activities in all the territories recognised as common lands, or comuni (Placanica 1999, 166).

\section{A political geography of the commons in Sila}

While legal documents provide exhaustive information on the institutionalisation of the universitas casalium, the material life of its communities is rather neglected. Of what did these traditional practices consist? What form did they take on the rugged ground of Sila? We need to take several steps forward in time in order to find reliable information on the essence of traditional practices based on collectivism. The most reliable information was collected during a territorial inquiry led by Judge Giuseppe Zurlo in 1791, aimed at re-establishing the original borders of common lands, thus revealing illegal occupations. Zurlo's inquiry also revealed several patterns of collective action in Sila, and identified the different customary rights that local commoners possessed on each territory (see Table 2).

The most widespread type of juridical land classification in Sila was known as comuni, universal domain lands where several traditional activities were allowed, depending on the characteristics of the territory. Zurlo's inquiry revealed the presence of 148 common lands all over Sila, whose borders were described in detail and their legal status reasserted (Zurlo 1866 vol. I, 185). For example, in the territories of Cotronei there were several common lands with different customary rights. An example was the territory known as Cocciolo, where local commoners were allowed to freely sow and plough (cesinare), and had to pay to the Crown a tenth of their harvest. Other customary rights included gathering nuts from local trees in order to feed the animals that they brought to pasture - both cattle and sheep. Taxes on pasturage varied according to the type of animal: for sheep the tax amounted to ten silver coins (carlini) for every hundred animals, while for cattle the arrangement depended on the economic activity of the farmer, totalling a maximum of five coins per animal. This tax was normally only collected for five months of the year, given the seasonal nature of animal grazing on the mountains of Sila during late spring and summer - the so-called transhumance (Zurlo 1866 vol. I, 135-136). As it will be shown in the following paragraph, the presence of a taxation system was not necessarily a detriment to the liberties of local commoners, as it actually worked against free-riding and illegal occupation. Nevertheless, there were also taxfree common lands in Sila, where customary rights did not require any payment. A good example are the territories surrounding Longobucco, whose pasture lands were open to all the herders who inhabited the universitas casalium, allowing their animals to pasture on local grasslands and to feed on wild nuts (Zurlo 1866 vol. 1, 139-142).

On the other hand, within the borders of partially private lands known as terre corse only pastoral activities were allowed, while other customary practices such as sowing and ploughing were the exclusive right of the landowner (Privilegii 1557, 48). As demonstrated by a decree of King Alphonse of Aragon going back to 1475, this was the only individual right in Sila until the rise of feudal landowners (Zurlo 1866 vol. 1, 166-167). A third type of territorial division was the so-called camere chiuse, or camere riservate, woodland areas containing the most precious trees - mainly pines, but also beeches and spruces - that the royal navy utilised for the construction of naval equipment. While these territories enjoyed the status of royal domain lands, they could be 
Table 2. Patterns of collective action on the lands of Sila

\begin{tabular}{|c|c|c|}
\hline Name of land & \multicolumn{1}{|c|}{ Legal status } & Practices allowed to Universitas \\
\hline $\begin{array}{c}\text { Common lands } \\
\text { comuni) }\end{array}$ & $\begin{array}{c}\text { Universal domain lands completely } \\
\text { open to traditional activities for } \\
\text { members of the universitas }\end{array}$ & $\begin{array}{c}\text { Every traditional practice } \\
\text { depending on the characteristics } \\
\text { of the territory }\end{array}$ \\
\hline $\begin{array}{c}\text { Partially private } \\
\text { lands (terre corse })\end{array}$ & $\begin{array}{c}\text { Feudal or royal domain lands } \\
\text { belonging to either the Crown, } \\
\text { the feudal barons or the middle } \\
\text { class }\end{array}$ & $\begin{array}{c}\text { Agricultural activities as an } \\
\text { exclusive domain of the owner, } \\
\text { but pastoral activities allowed }\end{array}$ \\
\hline $\begin{array}{c}\text { Lands owned by the } \\
\text { monarchy } \\
\text { (camere chiuse })\end{array}$ & $\begin{array}{c}\text { Royal territories destined for wood } \\
\text { extraction for the construction of } \\
\text { naval vessels }\end{array}$ & $\begin{array}{c}\text { Wood gathering and cattle raising } \\
\text { when possible }\end{array}$ \\
\hline
\end{tabular}

located inside common territories, feudal domain lands, or even private properties (both terre corse and later on difese). This allowed the exercise of some customary practices, such as the so-called legnatico - the right to gather woods from fallen tree branches - used by local commoners for essential subsistence activities such as cooking food and heating homes. Moreover, just as in the case of terre corse, animal pasture was an unalienable right (Zurlo 1866 vol. 1, 167-168).

While Zurlo's inquiry managed to provide a first-hand account of customary rights in Sila, his research also demonstrated the presence of longstanding governance arrangements. As will be shown in the next paragraph, an analysis of the legal documents produced by the universitas casalium reveals the existence of a polycentric governance system, where several actors disputed different functions, generating conflict but also mutual arrangements that kept the situation stable, at least until the rise of feudal landowners.

\section{Governance arrangements of the universitas casalium: polycentricity and adaptability}

Since its institutionalisation in the late twelfth century, the universitas casalium was mainly a consultative organ, organising customary rights through a complex governance system with multiple representation levels. Every hamlet reunited the heads of local households in small local parliaments known as cedole. Two elected representatives for each hamlet then joined the universitas general assembly - the so-called consiglio - that met in the mother-church of Cosenza (the Church of Saints Philip and Jacob). Four main institutional figures were in charge of moderating the assemblies (Cozzetto 2009, 82). Three of the elected people were called sindaci and had a representative function, negotiating usufruct arrangements with the Crown. The fourth representative - called mastrogiurato - was in charge of monitoring processes, guaranteeing compliance with governance arrangements (Cozzetto 2005, 277).

Remarkably, balanced representation was guaranteed, as each of the three sindaci belonged to a different social stratum (see Table 3). Early evidence is constituted by a document dating as far back as 1381, in which three representatives are invited by Queen Joanna I (1326-1382) to negotiate better legal terms of community usufruct: a representative of the local army (Antonio De Viso), a member of the church (Cicco Migliares) and an ordinary citizen (Jacopo di Giuseppe) (Privilegii 1557, 2). Other valid historical proofs of the sindaci's negotiating power are two documents compiled on 6 September 1414. In the first one the sindaci criticised some royal functionaries who had denied 
Table 3. Governance within universitas

\begin{tabular}{|c|c|c|c|}
\hline Name & Membership & $\begin{array}{c}\text { Number of elected } \\
\text { representatives }\end{array}$ & Function \\
\hline $\begin{array}{c}\text { Local } \\
\text { parliaments } \\
\text { (cedole })\end{array}$ & $\begin{array}{c}\text { Representatives of } \\
\text { every household }\end{array}$ & One representative & $\begin{array}{c}\text { Representing the local } \\
\text { hamlet in the } \text { universitas }\end{array}$ \\
\hline $\begin{array}{c}\text { General } \\
\text { assembly of } \\
\text { (coniversitas }\end{array}$ & $\begin{array}{c}\text { Elected } \\
\text { representatives }) \\
\text { from every cedola }\end{array}$ & $\begin{array}{c}\text { Four representatives } \\
\text { (three sindaci and } \\
\text { one mastrogiurato })\end{array}$ & $\begin{array}{c}\text { The three sindaci } \\
\text { represented the } \\
\text { universitas } \text { with feudal } \\
\text { barons and the king, while } \\
\text { the mastrogiurato } \text { was in } \\
\text { charge of local security } \\
\text { and of monitoring against } \\
\text { free riders }\end{array}$ \\
\hline
\end{tabular}

the inhabitants' pasture rights and exhorted Queen Joanna II (1373-1435) to replace her monitors (Privilegii 1557, 8-10). The second one was even more audacious, as it requested the queen to grant universal citizenship rights to all inhabitants of the universitas casalium (Privilegii 1557, 10-11). The queen's granting of this request, made official by a judicial act of 1416 , was therefore a judgement call, a conciliatory measure in order to maintain public order (Privilegii 1557, 11-12).

The functionality of representation mechanisms was essential in order to favour balanced negotiations among representatives of the two main poles of the governance system, thus mitigating both political and economic risks. By the second half of the fifteenth century, the universitas casalium was one of the most developed institutions of Southern Italy, with a population of over 25.000 people and 69 hamlets in total - second only to the municipal area of Naples (Cozzetto 2009, 69). This was mainly due to the administrative freedom that the municipal organisation enjoyed, as witnessed by a document dated 15 June 1422, in which numerous customary rights were renewed, determining the moment of greatest autonomy for this institution (Cozzetto 1987, 76). An example is provided by the concession of legal rights to sow on common lands for all citizens of the universitas in exchange for a small part of their harvest. The same regulation applied to cattle farming, a fundamentally tax-free activity, unless the animals were employed for ploughing, in which case local citizens needed to pay a tax of one golden coin (tari) per cattle. Perhaps more importantly, the exchange of goods on common lands was absolutely tax-free for members of the institution, while foreigners needed to pay an extra tax to the universitas. To this protectionist economic measure corresponded a very open membership system: every family representative living in the jurisdiction of Cosenza and its hamlets could join the institution and enjoy all the resulting economic privileges. Moreover, in order to avoid conflicts of interest, members of the universitas casalium were forbidden to hold royal office and exempted from state obligations, such as the unpopular corvée. This functional, endogenous governance system was complemented by a strong sanctioning apparatus controlled by the local mastrogiurato, whose main task was to protect common lands from free-riders. Infractions were punished with a fine amounting to two-and-a-half copper coins (grana). The universitas also demanded that the monarchy monitor royal functionaries in order to prevent possible abuses against the citizens (Privilegii 1557, 14-24). This created a balanced monitoring system, consisting of a two-tier structure that allowed the universitas casalium to 
exercise its customary rights through self-organisation. All the details described in this local statute present a picture of this institution as a healthy one, based upon a functional governance system in line with Elinor Ostrom's yardstick rules - balanced representation, monitoring and sanctioning systems, well-defined boundaries and most importantly, institutional recognition from the state.

However, if the institutional recognition of the universitas casalium demonstrated the Crown's will to assimilate collective action, allowing it to thrive under state control, it also subjected it to destabilising exogenous forces. While the endogenous administrative divisions of Cosenza and its hamlets - represented respectively by cedole and consigli - functioned essentially as a local governing system, a second, top-down institutional jurisdiction was also claimed by the Crown. The previously-mentioned bagliva was not only a tax to be paid to the royal government, but also a governmental pattern of jurisdictional partition, which divided the territory of Cosenza and its hamlets into 19 districts, or baglive (Cozzetto 1986, 141-144). Thus, the people appointed to collect the bagliva tax - known as baglivi - also functioned as royal delegates with administrative roles, mostly guaranteeing institutional protection in case of illegal land occupation (Parrilli et al. 1824, 61). In the light of this 'two-headed' normative structure (see Figure 1), one could maintain that the functioning of the universitas casalium consisted of a polycentric governance system: both commoners and state institutions possessed their own separate bureaucratic apparatuses that interacted with each other but also functioned independently (Cozzetto 2009, 79).

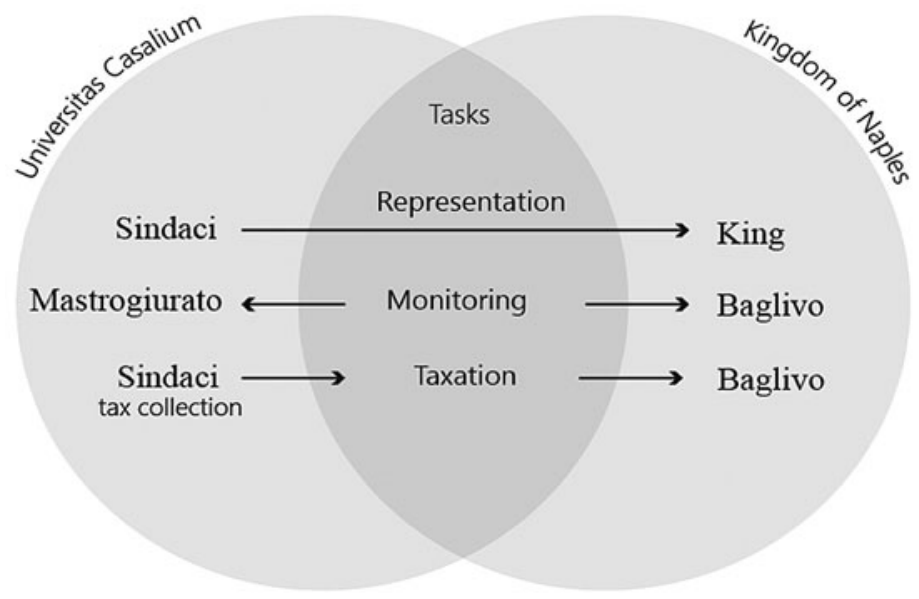

Figure 1. Polycentric governance systems on Sila's domain lands: roles and tasks

However, while effective representation incentivised the economic expansion of the institution and favoured its political consolidation, the overlapping of different and equally recognised jurisdictions also generated controversies. Perhaps the major issue concerned the regulations granting access to common lands. While the common lands of Sila were protected by secular consuetudinary norms that were as respected and unified as state laws were, their nature as royal domain lands granted the Crown effective ownership of local natural resources (Privilegii 1557). Therefore, although local communities were considered 'the real owners of those lands' they had no power to draft new laws and had to continually negotiate the usufruct of these lands with the Crown through local legal acts known as 'privileges' (Parrilli, Winspeare and Giannattasio 1824, 3). Another problem was constituted by monitoring structures, since national and local functionaries - respectively, baglivi and mastrogiurati - had similar tasks. Although the 
former mostly acted as tax collectors, they also had to ensure that local citizens would comply with land regulations. This task overlapped with that of the local mastrogiurato, in charge of guaranteeing internal security and the respect of common rules. While there is no evidence of direct disputes between these two figures, documentary evidence demonstrates a slow decay of the mastrogiurato since the second half of the fifteenth century (Cozzetto 2005, 277). This gave a green light to the baglivi to exercise exclusive power over monitoring processes. As witnessed by multiple queries from local representatives, the rise of baglivi tended to increase illegal land-grabbing, as the lack of effective monitoring processes favoured the corruption of royal officials (e.g. Privilegii 1557, 19 and 23). Monitoring and taxation were closely related, as the latter consisted of a 'two-headed' or dual system with the figure of the baglivo at the core. Representatives of the universitas collected taxes from local citizens in order to pay the bagliva to the royal functionary in charge (baglivo). Naturally, the Crown had the power to decide whether to increase tax concessions or not, while local communities could not join the conversation. Historical evidence suggests that the lack of local representation in terms of tax impositions created discontent and unrest. In several cases citizens complained about the arbitrariness of the local baglivi in collecting taxes, asking the Crown for more equitable and defined criteria (Privilegi et capitoli, 1557, 100). In other cases, they resorted to armed protests - the most notable being a revolt that occurred in 1461 against the increase of the bagliva tax, which was stifled by military occupations (Cozzetto 2005, 283). This event was a point of no return for the universitas casalium: a few years after the occupation, the newly elected King Ferdinand II of Aragon started a reformist campaign aimed at reorganising local institutions.

The institutional structure of the universitas casalium was thus characterised by different governance centres that acted both at a local and a national level, with similar tasks. In this sense, one could consider the governance system of collective resources in Sila as polycentric. As Elinor Ostrom has observed in regard to polycentric governance systems, in Sila several conflicts arose because of the interdependence between them, but that also gave rise to collaborative strategies to face new challenges and solve different issues $(2005,286)$.

However, the political reforms promoted by the Aragonese monarchy after 1461 would signal a progressive dissolution of this polycentric governance system and oversee the slow decay of collective action in Sila. The following provides documentary evidence of the major historical developments in the universitas casalium after being sidelined by centralising political reforms; in particular, the reconstruction below illustrates the processes that led to the slow decline of collective action in favour of state centralisation and agrarian individualism.

Changing governance arrangements: the slow decline of the universitas casalium

The legislative measures promoted by King Ferdinand I (1423-1494) radically reformed the universitas casalium, initiating its gradual yet inexorable decline, in spite of official pleas by local representatives, who asked for the restoration of their rights (Privilegii 1557, 33-41). A decree promulgated on 22 November 1472 relegated local functionaries to marginal representative roles and the institution was subjected to Crown rule. Moreover, the king stripped the universitas casalium of its freedom to associate autonomously, threatening transgressors with expulsion from the organisation. The institution was also deprived of its parliamentary autonomy, as an appointed royal representative had to convene members of the consiglio and attend every official meeting. The appointed representative also held veto power in every deliberation of the assembly. Perhaps more importantly, the king reserved the right to have the final word on the election of both local sindaci and mastrogiurati, who could not make any decision without publicly submitting it to parliament's approval (Privilegii 1557, 24-28). 
The loss of power of the universitas casalium as a central institution was accompanied by unprecedented levels of fiscal pressure, not only as far as the bagliva tax was concerned, but also on the exportation of silk, one of its flagship enterprises (Privilegii 1557, 123). The first popular upheavals were caused mainly by the new fiscal regime imposed on goods production, in particular the granetteria tax on silk; and further major troubles were on the way. The weakening of collective action opened the door to the emergence of local barons. While feudal lords had played a rather marginal role in the territories of Sila, they were able to slowly penetrate the upland territories, moving through what Fausto Cozzetto has defined as 'the geopolitical corridor from Cosenza to Amantea' $(2005,266)$. This initiated the so-called contenzioso silano - literally, the 'Sila litigation' - a conflict between feudal barons attempting to extend their possessions by enforcing the privatisation of large portions of common lands and local commoners defending their rights to collective action (Zurlo 1866, vol. III, 371) (also see Table 4). Evidence of the litigation first appears in 1481, when the members of the universitas casalium pointed out the impossibility of passing through some of the terre corse with their cattle without being taxed, and demanded that the Crown make amends (Privilegii 1557, 55). Following this first piece of historical evidence, complaints against illegal occupations of common lands become a leitmotiv in legal documents produced at the end of the fifteenth and the beginning of the sixteenth centuries, in most cases accompanied by requests to sanction illegal occupants (Privilegii 1557, 59-102). The political will to expand the power of landowners at the expense of commoners is confirmed by a constitutional reform of 1497, dividing the local council according to three different social classes: eight representatives were assigned to the nobility, four to the emerging middle class and four to local commoners (Privilegii 1557, 67). However, the latter were virtually excluded from relevant administrative roles, as witnessed by the lack of representatives from local communities in future consultations with the Crown (Cozzetto 1987, 82-85).

The Sila litigation was therefore the beginning of a slow decline of collective action, although the demise of customary rights was only made official with the unification of the Italian peninsula in 1861. A quick glance at the events of the next centuries confirms this interpretation. The litigation between feudal landlords and local commoners became more complicated between the late seventeenth and early eighteenth centuries, with the emergence of an ambitious middle class, known as galantuomini, embodying the liberal credo of free markets and privatisation (Basile 1958, 68).

Given the progressive loss of autonomy, legal action became the main protection strategy for local communities. As reported by an anonymous document written by a forest inspector as early as 1662, 227 trials for illegal land-grabbing had been registered (Lefosse 1997, 103). Moreover, documentary evidence suggests a total of 138 trials in Sila between 1721 and 1805, related both to land grabs and to illegal arson in local woodlands in order to convert them into territory for intensive agriculture (ASN, Delegazione della Regia Sila, fasc. 14-24). If after the institutional reforms that occurred in the late fifteenth century the universitas casalium did not possess enough autonomy to protect itself from privatising attacks, the kingdom's support was also unpredictable and often inconsistent. For example, while in 1791 the Bourbon monarchy appointed Giuseppe Zurlo to produce the aforementioned inquiry on land distribution in Sila, just one year later the Crown promulgated a set of laws - known as Praxis XXIV: De Administratione Universitatum aimed at abolishing universal domain lands all over the Kingdom of Naples, thus favouring the rise of agrarian individualism (Zaccagnini and Palatiello 1984, 15). This conflict-laden scenario encompassed the most marked tendencies of the time: the need to adapt institutional structures to a new socioeconomic system based on individualism and private property and the progressive clash between a modern bourgeoisie on the rise and a traditionalist class of staunch commoners 
Table 4. Mapping the Sila litigation

\begin{tabular}{|c|c|c|c|c|}
\hline Milieu & $\begin{array}{l}\text { Actors } \\
\text { involved }\end{array}$ & & & \\
\hline & $\begin{array}{l}\text { Kingdom of } \\
\text { Naples }\end{array}$ & Feudal barons & $\begin{array}{c}\text { Middle class } \\
\text { (mainly after } \\
\text { nineteenth } \\
\text { century) }\end{array}$ & Commoners \\
\hline Legislation & $\begin{array}{l}\text { National laws } \\
\quad \begin{array}{l}\text { conferring } \\
\text { absolute } \\
\text { powers to the } \\
\text { Crown }\end{array}\end{array}$ & $\begin{array}{l}\text { Feudal privileges } \\
\text { regulating the } \\
\text { possessions of } \\
\text { local barons }\end{array}$ & $\begin{array}{l}\text { Laws encouraging } \\
\text { land privatisation } \\
\text { after the } \\
\text { Napoleonic } \\
\text { decade (1805- } \\
1814)\end{array}$ & $\begin{array}{l}\text { Traditional } \\
\text { consuetudinary } \\
\text { norms shaping } \\
\text { material life } \\
\text { belonging to the } \\
\text { universitas casalium }\end{array}$ \\
\hline $\begin{array}{c}\text { Type of } \\
\text { land }\end{array}$ & $\begin{array}{l}\text { Closed } \\
\text { chambers } \\
\text { (Royal } \\
\text { domain } \\
\text { lands) }\end{array}$ & $\begin{array}{l}\text { Feudal domain } \\
\text { lands }\end{array}$ & $\begin{array}{l}\text { Enclosures, or } \\
\text { private lands } \\
\text { (since seventeeth } \\
\text { century) }\end{array}$ & $\begin{array}{l}\text { Common, or universal } \\
\text { domain lands }\end{array}$ \\
\hline
\end{tabular}

(Bevilacqua 1993). A significant sector of society was advocating the privatisation of universal domain lands as a way to implement more modern patterns of economic development. These tendencies became even more pronounced during the ten years of French occupation in the early nineteenth century (1805-1815). From a regulative standpoint, the 'Napoleonic decade' meant the formal abolition of the feudal system - the so-called eversione della feudalità - and the consequent privatisation of common lands, which were redistributed among local landowners (Lombardi $1885,84)$. By the time the French occupation ended, common lands had been almost completely privatised all over the Kingdom of Naples and universitas had almost completely disappeared. The institutional attack on collective action initiated in the second half of the fifteenth century would finally come to a close with the unification of the Italian peninsula in 1861. The new political reforms, aimed at satisfying the energy-intensive needs of the newborn Italian state, would lead to the progressive erosion of collective action all over the peninsula, as commons were further marginalised in favour of private property and mechanised agriculture (Corona 2009). This phenomenon echoed a reformist political campaign that involved all Western Europe during the nineteenth century, predicated on a fundamental abolition of the commons (De Moor 2017, 1). In the case of Sila, it translated into a series of legal efforts promulgated between 1865 and 1877: a major part of remaining common lands was sold to private landowners, while the rest was granted to local municipalities for the construction of roads and railway lines (Legge e regolamento sulla Sila Regia 1877). Just as collective action in the Italian peninsula had been first assimilated by the municipal institution during the Middle Ages, as demonstrated by the case of the universitas casalium, the discordant historical trajectories of Northern-Central and Southern Italy converged again, one last fatal time, destined to follow the same narrative of progress and modernisation (Corona 2009, 96). 


\section{Conclusion}

This essay has attempted to draw a comprehensive picture of collective action in Southern Italy, comparing the Italian Mezzogiorno to the rest of the country. In retracing the medieval fragmentation of customary rights in the Italian peninsula, it has found some common characteristics between different Italian regions that correspond to Putnam's idea of 'systematic regional differences', leading to 'a powerful monarchy in the south and a remarkable set of communal republics in the centre and north' $(1993,16)$. While it is a fact that divergent historical trajectories created different political structures in the Italian peninsula, this did not necessarily imply the dissolution of collective action in the South, as patterns of common ownership were incorporated in Germanic laws, creating effective governance arrangements based on polycentrism. As the historical reconstruction undertaken here clearly indicates, the progressive dissolution of collective action in Sila should not be attributed to the lack of effective governance structures, but to the centralising attitudes of royal institutions, whose reformist efforts eventually succeeded in eviscerating the power of the universitas casalium. The weakening of this institution also allowed the emergence of private landowners, as patterns of agrarian individualism gained prominence over collective action. Given the multiple issues associated with this topic, it appears clear that the study of collective action in Southern Italy could constitute a litmus test for interpreting the legal, political and environmental history of the Italian Mezzogiorno. Focusing on the period between the twelfth and fifteenth centuries could help in understanding the polycentric governance arrangements regulating collective action in Southern Italy. Complementarily, researching historical events between the fifteenth and nineteenth centuries could contribute to assessing the causes that led to the progressive dissolution of collective action, while at the same time retracing popular resistance against both agrarian and political individualism.

Through the case study on the uplands of Sila, this article has offered an example of collective action in the Italian Mezzogiorno as a complex yet functional polycentric system based on the juxtaposition of official laws and consuetudinary norms. As noted by Elinor Ostrom, 'polycentric systems can generate considerable conflict among the various units at multiple levels due to their interdependence', escalating 'from misunderstandings to ever more serious charges and countercharges that turn to violence'. In contrast, Ostrom also reminded us that to some extent 'conflict may, on the other hand, generate more information that is useful to participants in their efforts to solve challenging problems' $(2005,286)$. Both these assumptions are validated by the case study of the universitas casalium, an institution strongly embedded in consuetudinary norms that enjoyed state legitimacy as part of a dual system, where local and state power often overlapped. Although its policentricity did create controversies over those norms, it also generated functional governance arrangements, at least until its institutional undermining led to its slow dissolution, concluding in Italian national unification in 1861.

The example of Sila is not an isolated one. Although not explicitly referring to collective action, several studies have addressed the complex normative arrangements of Southern Italy, looking at the power struggles between the monarchy, feudal barons and local communities. ${ }^{1}$ Other historical reconstructions have focused on the socioeconomic forms of material life in the Kingdom of Naples, discussing customary rights as an economic pattern indissolubly tied to the normative efforts of the Crown (Basile 1958; 1989). Perhaps more importantly, some research has endeavoured to assess the socio-ecological consequences that resulted from the privatisation of royal lands in the aftermath of Italian unification (Branca 1883 and Marenghi 1909). While all these examples present their own political and normative specificities, they are also the result of the same institutional interplay, characterised by polycentric, dual governance systems. Framing this corpus in the historical 
literature within the critical perspective presented here could contribute to improved historical interpretations of the commons in Southern Italy, identifying commonalities and addressing specific territorial contingencies. As remarked by Elinor Ostrom 'the power of a theory is exactly proportional to the diversity of situations it can explain' $(1990,24)$.

\section{Acknowledgements}

This article is the result of a long research effort, initiated in 2016. Many are the people and institutes that have contributed to its making. Gabriella Corona and Alessandra Bulgarelli first introduced me to the topic of Southern Italian commons. Christof Mauch, director of the Rachel Carson Center for Environment and Society, encouraged me to produce an article on this topic after being acquainted with my research. He also revised several drafts of the manuscript, providing precious advice all the way. Other members of the RCC extended family, such as Roberta Biasillo and Monica Vasile, provided valuable comments on different drafts of this manuscript. The Andrea von Braun Foundation provided me with the financial means needed to dive deeply into this research with confidence and serenity. Vitória Fank Spohr revised the text multiple times, contributing to improving its lexical and stylistic contents. Special thanks also go to Modern Italy editor Mark Seymour, whose professionalism and commitment were essential for the completion of the publication process. Finally, I thank the anonymous referees who revised the article and shared their expertise.

\section{Notes on contributor}

Claudio de Majo is a $\mathrm{PhD}$ candidate at the Rachel Carson Center for Environment and Society (LudwigMaximilian University, Munich). He has carried out research with the University of Naples L'Orientale, the Institute for Housing and Urban Development Studies at Erasmus University of Rotterdam, the University of Utrecht and the Federal University of Minas Gerais, Belo Horizonte (Brazil). His publications include articles on the relation between collective action and ecology as well as on collective action in contemporary urban contexts. He is a founding member of the American Studies academic journal JAmIT! and editor of the Environmental History journal Global Environment.

\section{Note}

1. See for example Marino 1988 for the plains of Puglia; Bulgarelli 2015 for common lands in Molise; Armiero 1997 and 2002 for collective resources on the mountains of the Abbruzzi.

\section{References}

\section{Archival abbreviations}

Archivio di Stato di Napoli (ASN)

Envelope (bus.); folder (fasc.); years (a.); volumes (vol.).

\section{Primary sources}

ASN, Ministero delle Finanze, fasc. 11706, 'Corrispondenza tenuta col Commessario Civile dall'anno 1838 al 1850', vol. I-IV.

ASN, Ministero di Polizia, fascicolo n. 2298, a. 1840-1841 vol. IV.

ASN, Delegazione della Regia Sila, bus. 1-25. 
Barletta, P. 1864. 'Leggi e documenti anteriori all'anno 1806'. In Leggi e documenti antichi e nuovi relativi alla Sila di Calabria, vol. I-III.

Branca, A. 1883. 'Relazione del commissario comm. Ascanio Branca, deputato al Parlamento, sulla seconda Circoscrizione (provincie di Potenza, Cosenza, Catanzaro e Reggio-Calabria)'. In Atti della Giunta per la inchiesta agraria e sulle condizioni della classe agricola, 9 (1).

de Rivera, A. 1828. Memoria relativa allo scioglimento della promiscuità delle proprietà nella Regia Sila, Naples.

Legge e regolamento sulla Sila Regia, Rome 1877 (accessed from Fondazione Einaudi).

Lombardi, L. 1885. Delle origini e delle vicende degli usi civici nelle provincie napoletane. Naples: Tipografia Municipale.

Marenghi, E. 1909. 'Calabrie: relazione del delegato tecnico prof. Ernesto Marenghi'. In Inchiesta parlamentare sulle condizioni dei contadini nelle province meridionali e nella Sicilia, 5 (2).

Parrilli, B., D. Winspeare and G. Giannattasio. 1824. Dritti e Ragioni de' Comuni di Cosenza e de' così detti suoi Casali sul Demanio della Sila. Naples.

Privilegii et capitoli della citta de Cosenza et soi casali, Naples 1557 (accessed from Biblioteca del Senato).

Zurlo, G. 1866 (1791). Stato della regia Sila liquidato nel 1790 da Giuseppe Zurlo, vol I-III Naples: Stamperia Governativa.

\section{Secondary sources}

Alfani, G. and R. Rao. 2011. La gestione delle risorse collettive. Italia settentrionale, secoli XII-XVIII. Milan: Franco Angeli.

Armiero, M. 1997.'Boschi ed economie nell'Abruzzo dell'Ottocento'. Meridiana 30: 41-71.

Armiero, M. 2002. 'La ricchezza della montagna. Il bosco dalla sussistenza al superfluo'. Meridiana 44: 65-96.

Banfield, E. 1958. The Moral Basis of a Backward Society. Glencoe, IL: The Free Press.

Basile, A. 1958. Moti contadini in Calabria dal 1848 al 1870. Excerpt from the Archive for Calabria and Lucania, Year XXVII, fasc. I-II.

Basile, A. 1989. Baroni, contadini e Borboni in Sila. Rome: Gangemi.

Bevilacqua, P. 1993. Breve storia dell'Italia meridionale: dall'Ottocento a oggi. Rome: Donzelli.

Bonan, G. 2016. 'The Communities and the comuni: the Implementation of Administrative Reforms in the Fiemme Valley (Trentino, Italy) during the First Half of the Nineteenth Century. International Journal of the Commons 10 (2): 589-616.

Bonan, G. 2018. 'Natural Time and Bureaucratic Time. State Building, Forests and Environmental Conflicts in the 1800s'. Environment and History (forthcoming).

Bulgarelli Lukacs, A. 2015. 'I beni comuni nell'Italia meridionale: le istituzioni per il loro management'. Glocale. Rivista molisana in storia e scienze sociali 9-10: 119-138.

Cacciari, P., ed. 2010. La società dei beni comuni: una rassegna. Rome: Ediesse.

Carsile, K. and R. Gruby. 2017. 'Polycentric Systems of Governance: a Theoretical Model for the Commons' . The Policy Studies Journal August: 1-26.

Cassandro, G. 1943. Storia delle terre comuni degli usi civici nell'Italia meridionale. Bari: Laterza.

Cencelli, A. 1920. La proprietà collettiva in Italia. Milan: Hoepli.

Ciolli, M. 1982. 'Parco nazionale della Calabria'. In Parchi e riserve naturali in Italia. Milan: Touring Club Italiano: $155-167$.

Ciuffetti, A. 2015. 'Usi civici e spazi collettivi nell'Italia centrale. Alcuni percorsi interpretativi tra economie di rete, capitalismi mercantili e sistemi territoriali locali'. Glocale. Rivista molisana in storia e scienze sociali 9-10: 81-118.

Corona, G. 1995. Demani ed individualismo agrario nel regno di Napoli (1780-1806). Naples: Edizioni Scientifiche Italiane.

Corona, G. 2004. 'Paolo Grossi e la risposta italiana alla "Tragedy of the Commons"'. Frutti di Demetra 1: 9-15. 
Corona, G. 2009. 'The Decline of the Commons and the Environmental Balance in Early Modern Italy'. In Nature and History in Modern Italy, edited by M. Armiero and R. Hall, 89-107. Athens: Ohio University Press.

Corona, G. 2017. A Short Environmental History of Italy. Winwick, Cambs: The White Horse Press.

Cozzetto, F. 1986. Mezzogiorno e demografia nel XV secolo. Soveria Mannelli: Rubbettino.

Cozzetto, F. 1987. Territorio, istituzioni e società nella Calabria moderna. Naples: Guida.

Cozzetto, F. 2005. 'Una grande università: Cosenza e i suoi Casali. In Città e contado nel Mezzogiorno tra Medioevo ed età moderna, edited by G. Vitolo, 261-286. Battipaglia: Laveglia \& Carlone.

Cozzetto, F. 2009. 'Cosenza e i suoi casali nella prima età spagnola'. In La Calabria del viceregno spagnolo. Storia arte architettura e urbanistica, edited by A. Anselmi, 69-92. Rome: Gangemi.

De Moor, T. 2008. 'The Silent Revolution: A New Perspective on the Emergence of Commons, Guilds, and Other Forms of Corporate Collective Action in Western Europe'. International Review of Social History 53: 179-212.

De Moor, T. 2010. 'Participating is More Important Than Winning: the Impact of Socio-Economic Change on Commoners' Participation in Eighteenth- and Nineteenth-Century Flanders'. Continuity and Change 25: 405-433.

De Moor, T., M. Laborda-Pemán, J. M. Lana-Berasain, R. van Weeren and A. Winchester. 2016. 'Ruling the Commons. Introducing a New Methodology for the Analysis of Historical Commons. International Journal of the Commons 10 (2): 529-588.

De Moor, T. 2017. The Dilemma of the Commoners. Understanding Common-Pool Resources in Long-Term Perspective. Cambridge: Cambridge University Press.

Duggan, C. 2014. A Concise History of Italy. Cambridge: Cambridge University Press.

Galli, E. 1959. La Sila. Cosenza: Barbieri.

Grossi, P. 1977. Un altro modo di possedere. L'emersione di forme alternative di proprietà alla coscienza giuridica postunitaria. Milan: Giuffrè.

Intrieri, L. 2010. 'La ripartizione delle terre fra i comuni silani nel 1889'. Periodico dell'Istituto calabrese per la storia dell'antifascismo e dell'Italia contemporanea, 1: 5-30.

Lefosse, S. 1997. Ricerche su la origine delle proprietà territoriali e su la istoria della Calabria. Per il Regio Demanio della Sila. Dell'Ispettore Forestale della Calabria Citeriore R.P.. Rossano Scalo: Zeta.

Marinelli, F. 2000. Gli usi civici: aspetti e problemi delle proprietà collettive. Naples: Hoepli.

Marinelli, F. 2013. 'Usi civici e beni comuni'. Rassegna di diritto civile. 2: 406-422.

Marino, J. 1988. Pastoral Economy and the Kingdom of Naples. Baltimore: Johns Hopkins University Press.

Massullo, G. 2015. 'Beni comuni e storia'. Glocale, Rivista molisana in storia e scienze sociali. 9-10: 27-54.

Mocarelli, L. 2015. 'Usi civici e spazi collettivi in Italia settentrionale dall'età moderna a oggi'. Glocale, Rivista molisana in storia e scienze sociali. 9-10: 55-80.

Ostrom, E. 1990. Governing the Commons. Cambridge: Cambridge University Press.

Ostrom, E. 2005. Understanding Institutional Diversity. Princeton, NJ: Princeton University Press.

Pennacchi, L. 2012. Filosofia dei beni comuni: crisi e primato della sfera pubblica. Rome: Donzelli.

Placanica, A. 1999. Storia della Calabria dall'antichità ai giorni nostri. Rome: Donzelli.

Putnam, A. 1993. Making Democracy Work. Civic Traditions in Modern Italy. Princeton: Princeton University Press.

Raffaglio, G. 1939. Diritti promiscui, demani comunali, usi civici. Milan: Società Editrice Libraria.

Ricoveri, G. 2010. Beni comuni vs. merci. Milan: Jaca Books.

Sereni, E. 1997. History of the Italian Agricultural Landscape, trans. R. Burr Litchfield. Princeton: Princeton University Press.

Stagno, A. M. and V. Tigrino. 2013. 'Beni comuni e località: una prospettiva storica'. Ragion Pratica 41: 333-346.

Tallarico, G. 1950. La Sila ed i suoi valori. Rome: Ramo Editoriale degli Agricoltori S. A.

Thompson, E. P. 1991. Customs in Common. London: The Merlin Press.

Villani, P. 1977. Mezzogiorno tra riforme e rivoluzioni. Bari: Laterza. 
Wall, D. 2017. The Commons in History. Culture, Conflict and Ecology. Cambridge, Mass.: MIT Press. Zaccagnini, M. and A. Palatiello. 1984. Gli usi civici. Naples: Jovene.

\section{Italian summary}

L'obiettivo di questa ricerca è contribuire allo studio dei beni comuni nell'Italia meridionale attraverso l'indagine delle relazioni tra pratiche collettive e feudalesimo. Nell'analizzare la storia dei beni comuni nel Mezzogiorno e ponendo attenzione critica sulla governance di carattere policentrico sono state assunte le teorie di E Ostrom. Nello specifico, si propone un caso-studio condotto sull'altopiano Silano, dove i beni comuni furono istituzionalizzati attraverso la formazione dell'Universitas Casalium, organo (o organizzazione) municipale che raccoglieva la città di Cosenza e i suoi casali. L'esistenza di relazioni continue tra questo istituto e il governo reale portò alla nascita di un sistema policentrico di governance in cu diverse funzioni istituzionali si contaminavano in maniera controversa, generando conflitti, ma anche interessanti soluzioni. Considerata la produttività di tale sistema, suscita un certo stupore l'assenza da parte delle interpretazioni storiche precedenti di un approfondimento di questa situazione organizzativa. Le fonti documentarie analizzate in questa sede suppliscono a tale mancanza: se il riconoscimento istituzionale dell'universitas casalium può essere ricondotto al XII secolo, una serie di riforme istituzionali iniziate a partire dal XV secolo dalla corona reale determinarono un progressivo declino di questa istituzione e delle economie che da essa dipendevano. Questa perdita di legittimità corrispose all'emergere di una classe di baroni feudali e successivamente di possidenti notabili, determinando la fine dei commons in Sila, in corrispondenza all'unificazione nazionale del 1861. 